quite well, his appetite was good, but he still complained of pain about the middle of the sternum, which was increased on swallowing anything semi-solid. After a few weeks the child lost the pain, and forgot all about the halfpenny. He still remained in good health, despite the gloomy prognosis that some medical men who had been subsequently consulted gave of the case. Four months afterwards, while munching a cake, his father noticed him hiccough violently, and was surprised to find that he had brought up the halfpenny, which had turned quite black. I therefore conclude that this coin had been lodgerl somewhere in the oesophagus, and had no doubt given rise to the pain of which the child had complained. It would probably have been found and removed if the probang or coincatcher had been used in the first instance.

London Hospital, E.

\section{TOLERANCE TO FOREIGN BODIES IN THE TISSUES.}

By Launcelot ARcher, M.R.C.S.

ON Friday, Oct. 26th, a young lady consulted me in consequence of a painful swelling over the carpo-metacarpal joint of the little finger. On examination, I found that there was a small abscess in that situation, just pointing. I proceeded to open it, but felt the linife grate upon some hard substance as I cut down. Thinking there was a piece of dead bone, I carefully introduced the forceps and extracted a rough fragment of white marble about the size of a small bean. The patient could give me no explanation of its presence, but, on inquiring of her mother, she stated that when at school fourteen vears ago she fell on a newly made asphalt path and cut her hand severely. It was washed and strapped up, and healed without trouble. She felt no further effect from the injury until a week before I saw her, when she struck her hand against the table, and to that accident she attributed the formation of the abscess. The fragment was lodged deep down, just above the joint, and had apparently lain there quite inrocuously until the blow started fresh inflammatory action.

vincent-square, S.W.

\section{d a itlirror \\ OE}

\section{HOSPITAL PRACTICE, BRITISH AND FOREIGN.}

Nulla autem est alia pro certo noscendi via, nisi quamplurimas et morborum et dissectionum historias, tum aliorum tum proprias collectas habere, et inter se comparare.-MorgagNi De Sed. et Ccus. Monb. lib. iv. Proceminm.

\section{GUY'S HOSPITAL.}

COMPOUND DEPRESSED FRACTURE OF SKULL, WITH PARALYSIS OF EYE; TREPHINING; RECOVERY.-FOREIGN BODY IN THE EXTERNAL EAR, LEADING TO SUPPURATIVE OTITIS MEDIA AND PYAMI.1; DEATH; NECROPSY.

\section{(Under the care of Mr. BRYANT.)}

THE first of these cases is a good example of compound depressed fracture of the skull, in which, after removal of the outer table of bone, unusual cornminution of the inner table was found to an extent unsuspected before operation. The symptoms of a localised character in connexion with the right eye would appear to have been speedily cured by the removal of the depressed fragments of bone. The second case is an example of the sad consequences which may follow the thoughtless act of placing a foreign body in the external auditory meatus. Aural surgery lias only too many records the history of which is similar to this. A substance placed in the ear causes damage to the membrana tympani, which is followed by suppuration in the middle ear, extension of suppuration to the mastoid cells, the membranes of the brain, and death from pyamia. Too much care cannot possibly be taken in the extraction of substances from this situation, and parents should never let unskilled hands attempt it. Irreparable damage is often caused before the patient is seen by the medical attendant and the child is lucky if he escapes with partial deafness.

Compound depressed fracture of right frontal bone; con traction of right pupil; slow pulse; no other head symptoms, trephining and elevation, with removal of bone, including a large area of the inner table. (Reported by Mr. F. E. Williams.)-H. B-, agred twenty-eight, a labourer, was admitted on Feb. 16th, 1888, and discharged on March 31st 1888. A brick had fallen from a scaffolding, a distance of twenty feet, and struck the patient on the head. He was unconscious for two minutes after the blow, and was bronght to Guy's at once.

On admission, there was a clean vertical cut, about two inches in length, situated directly over the right frontal eminence; the bone was exposed nearly the whole length of the wound, forming a gutter (with markedly sloping sides), with considerable depression, an inch and a lialf long. The upper extremity of the gutter ended in a triangular depression, evidently produced by the angle of the brick. There was paralysis of the right eye, loss of sensation, loss of reflex, and also loss of movement of the muscles of the eyeball. There was considerable effusion of blood into the orbit; the pupils were unequal, the right being contracted and not reacting to light. No bleeding from the nose or ears. The patient had not been sick, and there was no paralysis or pain (the right eye excepted). The pulse was 54, and more irregular as to force of beat than as to time; the respiration was 20 Urine normal.

Feb. 16th. - About three hours after the accident chloroform was administered. During the administration of the anasthetic the patient was considerably convulsed, but not more on one side than the other. The wound was prolonged, and the periosteum raised from the eages of the gutter. A three-quarter inch trephine was applied at the upper extremity of the gutter, and a circular piece of bone removed; it was then seen how great the injury to the inner table was, for three-quarters of the area of the circle removed consisted only of the external table. On prising up the lower fragments, another crack, parallel and external to the former, was found to exist, and the intervening piece of bone came away. In all seven pieces of bone were removed, the inner being fractured over a far larger area than the external table; the dura mater was intact, and there was no effusion of blood between the bone and the dura mater. The edges of the wound were brought torether and two stitches inserted, and the wound dressed with iodoform and boracic gauze and Gamgee tissue. Leiter's coil was applied to the head. He was allowed barley water, half a pint of milk, and ice.

17th.-He passed a good night. Takes food well. There is considerable effusion into the right orbit. Temperature about $99^{\circ}$; pulse 46 .

18th.-The patient says he feels better. There is some subconjunctival hæmorrhage. Temperature about normal; pulse from 50 to 42 . Milk increased to one pint.

19th.-Leiter's coil discontinued. Pulsation of brain can be distinctly seen when dressings are removed.

20th.-Looks bright, and feels well. Takes his food well. Wound healed by primary union, except just at the upper end ; stitches taken out. Temperature from $99 \cdot 2^{\circ}$ to $97^{\circ} 4^{\circ}$ pulse 46. Allowed a pint of milk, and the same quantity of barley water.

2lst. - Enema of glycerine (a drachm) given. Both eyes react to light. Not much pain. Temperature from $99^{\circ}$ to $97^{\circ}$; pulse 48 .

24 th.-Rise in temperature to $100 \cdot 2^{\circ}$. Five grains of quinine were given at once, and the temperature came down to $99^{\circ}$. A little retained pus found at the upper end of the wound. The wound was opened, and a small quantity of pus came away.

25th. - He feels well. About three-quarters of a drachm of pus came away. 'Temperature $101^{\circ}$. The administration of more quinine was followed by a fall of temperature to $99^{\circ}$.

27th. - Wound opened more this morning and about a teaspoonful of pus came away. Is in good spirits, and answers questions readily.

March 2nd.-Patient's head dressed every morning with iodoform gauze. The wound progressed satisfactorily until the 15 th, when it was quite healed. On the 24 th he was permitted to walk about. A month later the patient was quite well. 